\title{
EL LUGAR DE LOS AFECTOS: LA CORRESPONDENCIA COMO PACTO EMOCIONAL DE DISTANCIA
}

\author{
POR \\ María InÉs Cisterna Gold \\ University of Massachusetts, Boston
}

Según Ricardo Piglia, “[v]ivir en un hotel es el mejor modo de no caer en la ilusión de 'tener' una vida personal, de no tener, quiero decir, nada personal que contar, salvo los rastros que dejan los otros" (14). La carencia del espacio propio hace que, en el extranjero, el hospedaje implique un lugar temporario, sometido a un tipo de excursión constante de espacios públicos -la exploración de la ciudad, sus lugares de encuentro, cafés, parques, hoteles, etc.-, así como el sitio mismo del hospedaje: la habitación, los pasillos, el lobby y la sala de espera que, a pesar de no ser propios para el viajero, terminan convirtiéndose en un espacio privado compartido.

En la literatura, el hotel siempre ha tenido un lugar privilegiado. Es una figura constante en el relato policial y de suspenso, que a través del anonimato y la predictibilidad que su estética ofrece, es escenario también de los secretos más íntimos de sus personajes. Según Bettina Mathias, "[a]s isolated places away from the familiar context of everyday life, hotels represent social laboratories for writers to test the stabilities of traditional value sistems, and they use the spatial limits of their setting to zoom in on a potential struggle that would be harder to detect in a less focused setting" (5). La experiencia del suspenso que la habitación de hotel evoca, es ideal para crear la ilusión de que existe algo más allá de la superficie, más allá de la simplicidad y la homogeneidad que proclama la cama, el escritorio, la mesa de luz, el espejo y la Biblia (Cisterna Gold).

Escribir en un hotel evoca el reconocimiento de una falta, la posibilidad de explorar entonces aquellas zonas de lo propio que esconden vínculos y zonas de intimidad pero que aportan un suplemento de sentido. Siguiendo la idea de Piglia, todo relato que se escribe desde los márgenes de su identidad, como puede ser el relato de viaje, exilio o de aventura, busca sin embargo, ser reconocido por su comunidad; desea, a pesar y gracias a la distancia, ser leído. De ahí que, como las cartas que Piglia encuentra en ese pequeño cuarto de hotel de La Plata que juntas componen el texto Formas Breves, los relatos que se escriben en los hoteles siempre reclaman del otro para continuar su propia historia. 
Edgardo Cozarinsky y Sergio Chefjec, dos escritores que han encontrado en el "extranjero" su lugar de residencia, se apropian del género epistolar en Vudú urbano y Los incompletos, respectivamente, como el modo más adecuado de transmitir el sentimiento de distancia e intimidad desde un lenguaje que se construye a partir del escaso espacio simbólico desde donde escriben sus personajes. Según Susan Stewart, la experiencia del desarraigo y desplazamiento, encuentra en la carta la manera de construir un objeto que cumple la doble función del souvenir: tanto en el objeto de la carta que se recibe, se interpreta y se guarda, así como el relato que se escribe, que narra un momento especial de la vida del sujeto, un relato que reivindica el pasado y la experiencia de contacto que se ha perdido, porque el presente se ha vuelto demasiado alienante como para vivirlo sin ser compartido (138). Esto es, las novelas que se construyen a partir de cartas, suponen "más sentimientos que hechos", ${ }^{1}$ porque el relato queda sometido al flujo emocional y corporal de la correspondencia siempre a la espera del reencuentro. Como un souvenir que en sí mismo llega a sustituir el objeto que éste recuerda, la necesidad de comunicar el sentimiento de la distancia se vuelve el propósito de las cartas aún más que lo que éstas expresan. Los afectos, según Jonathan Flatley, "[s]trictly speaking, [...] are always experienced in relation to an object" (16) así que imponen la presencia de un otro, un lector, un receptor que ponga en escena la manera en que el sujeto se conecta. Al convertirse la carta en el objeto en sí, la correspondencia se vuelve el escenario emocional desde donde se construye la comunicación.

Según Adriana Amante las cartas y las postales desde el exilio, recuperan el espacio del reencuentro. Dice Amante,

Los conjuntos de epístolas escritas desde el exilio están atravesadas por problemas espaciales: dislocaciones, distancias, viajes, itinerarios urbanos o internacionales, utopías o heterotopías: de manera que podemos pensar el género epistolar como un género de pasaje, que en las fronteras de la patria, recupera por la escritura el lugar simbólico de la reunión. (56)

Si bien Amante se refiere específicamente al género epistolar del siglo XIX como el lugar alternativo, el espacio político en que se construye el ideal de nación en la Argentina, las cartas en las novelas que nos interesan aquí a principios del siglo XXI proporcionan una posibilidad de encuentro y materializan el sentimiento de la distancia, desde un análisis aún más profundo sobre los sentimientos de legitimidad y fraternidad que la distancia genera. Ambos textos recuperan las posibilidades literarias y estéticas de las cartas y la correspondencia para dar lugar a una forma de comunicación que pone de relieve la manera en que la distancia hoy se vive y se siente: Ya sea durante la época

Cita en Adriana Amante, sobre una carta de Madame de Staël, 52.

Revista Iberoamericana, Vol. LXXXII, Núm. 257, Octubre-Diciembre 2016, 855-869 ISSN 0034-9631 (Impreso) ISSN 2154-4794 (Electrónico) 
de la posdictadura en el texto de Cozarinsky - como relato nostálgico del exilio que vuelve a la ciudad de su infancia a través de la mirada del turista que escribe tarjetas postales como forma de acceder a ese pasado- o bien, ya en el nuevo siglo en el texto de Chejfec, donde el sujeto desplazado presenta una manera incluso aún más ausente de intervenir en el discurso de la memoria y las prácticas del recuerdo. Sin embargo, las dos experiencias se materializan a través de pequeños escenarios y desde un deseo de contacto emocional, un momento auténtico e íntimo que valida el esfuerzo de la escritura. De esta manera los textos de Cozarinsky y Chefjec reflexionan en torno a la experiencia emocional de la escritura de la memoria y la relación afectiva entre escritor y lector como sujeto y objeto del recuerdo.

Se trata de textos que trabajan la figura del viajero/ escritor a través del cual se presenta un personaje en busca de una experiencia auténtica, sin mediación ni interferencias, que tiene como función relatar y reescribir lo vivido. Ambos autores postulan la posibilidad de narrar un texto que deambula en las fronteras de la autobiografía, en la que el personaje central del relato es uno que escribe su trayectoria para un segundo lector, otro que, como nosotros, debe interpretar las digresiones del viaje desde los límites de lo narrado. Ya sea en lo que describe y observa en los diferentes sitios que visita, así como en lo que relata y recoge del pasado. Este trabajo busca poner en escena el deseo de intimidad que narra el escritor de cartas, como relator de pequeños momentos que en la descripción de una escena o sitio, recoge la experiencia y la sensación, muchas veces físicas, de cómo está y vive ese momento de distancia. Sin embargo, ambos textos describen esa experiencia de maneras diferentes. Ambos apuntan al deseo de reconectar con el pasado a través del recuerdo de escenas porteñas y de la niñez del personaje autor como es el caso de Cozarinsky, o como el relato de Chefjec donde las escenas de la nostalgia operan desde un presente que no busca reconocimiento en la historia del pasado, sino un sentido en los detalles y la descripción de rincones de la vida en el extranjero, ya cuando parece que la deriva se ha convertido en la casa del escritor por excelencia (Adorno). Esto es, el personaje de Chefjec busca un valor ético en el contacto emocional y personal, una relación inmediata entre escritor y receptor del relato, que no depende de su participación en un contexto social o político que lo identifique.

En este sentido, he decidido hacer un análisis casi paralelo de estas dos novelas porque el trabajo de la memoria que aquí se presenta -aunque de dos épocas de enunciación diferentes, los años de la posdictadura y la década del 2000 en la Argentina-, refleja de todos modos, un reconocimiento de los sentidos como lugar afectivo desde donde se construye la subjetividad así como la relación con el otro. Desde esta perspectiva, se puede pensar en un tipo de "mapa afectivo" que estos textos construyen como forma simbólica de encarar el relato de la identidad, así como la relación del sujeto con su historia. En ambos textos, el cuerpo se convierte en el terreno que mediatiza

Revista Iberoamericana, Vol. LXXXII, Núm. 257, Octubre-Diciembre 2016, 855-869 ISSN 0034-9631 (Impreso) ISSN 2154-4794 (Electrónico) 
la experiencia afectiva y que pone de manifiesto la posibilidad de "afectar y ser afectado" en tanto la relación del sujeto con su entorno. Ya sea el lugar de la infancia, al que se regresa a través del recuerdo y la melancolía, o en el desplazamiento y la distancia que se manifiesta mediante la vida en el extranjero, en un hotel remoto, pero que ofrece un lugar donde se generan forces of encounter con el pasado, un espacio para pensar y reflexionar en torno a la intimidad. Según Gregory J. Seigworth, "affect is persistent proof of a body's never less than ongoing immersion in and among the world's, obstinancies and rhythms, its refusals as much as its invitations" (1).

Vudú urbano de Edgardo Cozarinsky se publica en el año 2000 a pesar de ser un conjunto de relatos escritos desde el exilio entre la década de los 70's y 80's. Se puede decir entonces que es un texto dedicado a reciclar la memoria; a reciclar en el sentido más moderno y contemporáneo, un uso y reuso de objetos. Este texto, entretejido también por diferentes narrativas, no distingue entre los relatos de los que se apropia; literaturas nacionales e internacionales, libros leídos y escritos, carteles publicitarios pintados en paredes, afiches, citas subrayadas y reescritas y, por supuesto, el filme. Todos en conjunto forman la sección del libro que se titula "El álbum de tarjetas postales del viaje". Una serie de textos breves que reencarnan una excursión al país natal del narrador y que se inicia con la primera parte llamada "El viaje sentimental". Esta sección, sin embargo, es una escena traumática de regreso ficcional del narrador a Buenos Aires, en la que el personaje se reencuentra con viejos amigos que lo acosan por haberse ido y le cuestionan sus intenciones al intentar regresar. Desde este punto de partida, el texto posiciona al narrador en un afuera ideológico, en el que él mismo se cuestiona la legitimidad de su propio discurso y es por eso que comienza un recorrido turístico de la ciudad que dejó atrás.

Se trata de un texto donde la escritura de las tarjetas postales asume una mirada de turista como forma de expresar una distancia aún mayor que la geográfica: por un lado reconoce la distancia y por otro expresa el deseo de establecer una relación íntima con el objeto para crear así la "ilusión de autenticidad" que justifique la escritura (Abbeele, "Sightseers" 6). Un tipo de alejamiento filial que le permite al sujeto recobrar ciertas escenas del pasado distanciándose de otras. Dicho presupuesto hace que el narrador pueda reflexionar en torno a cuestiones de legitimidad a la hora de pensar en el relato de la memoria. ¿Qué lugar tiene este narrador con respecto a la historia argentina y a su propia historia? ¿Qué lugar ocupa esta voz en el espacio discursivo y en el campo cultural argentino?

Desde esta perspectiva, una figura de autor que asume la postura de turista, a pesar de sus connotaciones de trivialidad y su espíritu exotizante, debe pensarse, hoy en día, como sugiere Georges Van den Abbeele, como un tipo de "producción teórica", un gesto crítico que posibilita el estudio de los discursos epistemológicos que constituyen la identidad nacional.

Revista Iberoamericana, Vol. LXXXII, Núm. 257, Octubre-Diciembre 2016, 855-869 ISSN 0034-9631 (Impreso)

ISSN 2154-4794 (Electrónico) 
On the one hand the tourist is motivated to leave by a sense of the inauthenticity of his own milieu. On the other hand, it can be asked whether the tourist is ever fully re-integrated into society, that is if he ever fully returns from his trip. Not only may his home have changed in the course of his trip, but the tourist's perception [...] may return home with a 'foreigners perspective' on it. ("Sightseers" 12)

Esta cita, proveniente de una reseña que hizo Georges Van den Abbeele del libro The Tourist: A New Theory of The Leisure Class (1976), de Dean MacCannell, usa la misma idea de economía de viaje que presenta unos años después en su libro Travel as Methaphor. From Montaigne to Rousseau (1992). El viaje, como gesto crítico, postula el riesgo a desestabilizar la sociedad de la que proviene el viajero, tanto o más que el peligro que pueda causar en la sociedad que visita. Desde esta perspectiva, Van den Abbeele lee el concepto de excursión o sightseeing que usa MacCannell, como la manifestación moderna de una ciencia cultural y, al turista, como un tipo de etnógrafo social en busca "información social auténtica".

Según Van den Abbeele, la teoría del turismo y la admisión del turista como miembro legítimo de las ciencias sociales, saca a relucir un tipo de viaje que también merece ser estudiado en tanto que aporta al estudio de las construcciones sociales como una consecuencia de las realidades posmodernas y posnacionales. De esta manera, las configuraciones teóricas que separan y problematizan las diferentes experiencias de viaje -cambios de lugar y residencia, desplazamiento, el regreso o la pérdida del hogarpresentan otra manera de analizar el valor categórico del lugar de origen y del territorio al que pertenece el sujeto. La diversidad de experiencias, sin embargo, como consecuencia de la imposibilidad de establecer un lugar sedentario para el sujeto, demuestra que el viaje y su teorización, se ha vuelto el espacio desde dónde estudiar nuestro presente, dado que este estudio no solo pone en escena la narrativa personal del viaje y el sujeto que lo emprende, sino que también saca a relucir la manera en la cual las diferentes sociedades reciben al extranjero. Espacio crítico y contestatario donde se cuestionan las repercusiones ideológicas de la totalización de nuestras realidades políticas y prácticas científicas del pasado, así como las estrictas maneras en que se han pensado los viajes turísticos, etnográficos o de exilio.

Vudú urbano postula la figura del turista y la del exiliado como las dos caras, los dos lados de la tarjeta postal, en la que se proyecta una imagen para luego narrar un deseo de regreso o, por lo menos, de identificación con un hogar que ya no existe. Las tarjetas postales constituyen el souvenir y la prueba del viaje del turista, así como el artefacto que representa un signo de legitimidad o, por lo menos, la inclusión superficial al lugar que se visita. Son objetos de producción masiva que, como apunta Susan Stewart, "move history into private time" y se caracterizan por un proceso de "capturing and display" que repiten la transformación de la recuperación del objeto público en la experiencia privada de la escritura del mensaje que enmarca "lo social"

Revista Iberoamericana, Vol. LXXXII, Núm. 257, Octubre-Diciembre 2016, 855-869 ISSN 0034-9631 (Impreso)

ISSN 2154-4794 (Electrónico) 
(138). Las tarjetas postales constituyen la transacción entre una fotografía o imagen de un lugar de interés, lo que MacCannell denomina marker, y el texto que narra la experiencia cultural que le ofrece al turista una conexión más íntima con la sociedad en la que el viaje se lleva a cabo.

Todos los tipos de viajes de los que Cozarinsky se apodera, responden a problemáticas parecidas en las cuales el retorno al hogar puede resultar un evento traumático, al revelar la imposibilidad misma de un regreso a una experiencia de identidad e identificación plena con el lugar de origen. De hecho, el primer relato "El viaje sentimental" en el que se narra el viaje de regreso al Buenos Aires del narrador y en donde se reencuentra con sus viejos amigos, inaugura el viaje turístico; es un viaje traumático del cual el narrador debe escapar y en el cual se debe negociar el derecho a rehabitar su propio lugar aunque sea de visita. Una vez que se encuentra con sus amigos, estos le cuestionan su estatus de "extranjero" y su vida de transeúnte: “-¿No te cansaste de ser turista? ¿No viste ya bastantes catedrales, palacios y museos?" (48). Esto implica que el deseo del narrador de usar los tropos turísticos y una mirada etnográfica para narrar su pasado, pasa primero por el juicio y la aprobación de los huéspedes que lo reciben, para justificar la legitimidad de su experiencia.

El narrador de "El álbum de tarjetas postales del viaje" se emprende en una "incursión turística” (Amante 124) de imágenes, discursos, deseos y metáforas, como elementos que se relacionan entre sí para crear un objeto y recrean un mapa tropográfico que le permite describir diferentes escenas de su país natal. Los diferentes sitios turísticos que marcan el itinerario del narrador no se presentan como lugares exóticos o excepcionales sino, más bien, como ruinas en las cuales yacen las reliquias de la nostalgia. Las tarjetas postales según Cozarinsky “fijan y reproducen el aspecto más típico de un paisaje, de un monumento o un rostro, estos textos quieren fabricar imágenes públicas y comunes, un déjà $v u$ donde diluir lo que puede haber de demasiado subjetivo en una experiencia y una sensibilidad individuales" (165). Si el relato de viaje tradicional así como los viajes turísticos, inscribían en sí mismos la distancia, las tarjetas postales, en tanto souvenirs, eran formas simbólicas de resaltar la extensión de lo recorrido, lo arduo y lejano del viaje. El viaje que emprende Cozarinsky, sin embargo, resalta una inmediatez, lo abrupto del viaje del recuerdo.

Juan José Sebreli le ha atribuido a Cozarinsky una "vocación de reconstructor de atmósferas desaparecidas" (216), que es de alguna manera la experiencia que incita el déjà $v u$, la reencarnación de hechos aislados e insignificantes que solo tienen validez para el que los recuerda, pero que aparecen como un flash, inesperados y que desaparecen repentinamente dejando solo la sensación de un recuerdo, cuya huella (impresión) solo se materializa en el cuerpo, pero que vuelve difícil la representación de un origen específico. De hecho, las tarjetas postales de Vudú urbano fueron escritas primero en inglés, "un inglés de extranjero" - dice Cozarinsky-, "[...] para borrar la 
noción de original, para que ciertos giros hallados al traducir, sean luego incorporados en la lengua traducida, hasta que el original mismo sea traducción" (165). La lengua traducida, en su otredad, añade otra capa de significado a las ruinas referenciales creando, pues, los monumentos a los que el turista se quiere acercar y reconocer. A su vez, el título en inglés y entre paréntesis de cada texto o tarjeta postal, le atribuye al contenido un significado casi arbitrario, fuera de lugar y exótico.

Sin embargo, la experiencia que se relata une las lenguas y los sentidos, y crea una escena que mezcla la sensación del recuerdo con escenas de la vida urbana, pero que siempre apunta hacia un tratado sobre el lenguaje, hacia una topografía que intenta demarcar, aunque sea por un momento, el proceso mismo que construye el lugar geográfico y el identitario. La ciudad aparece, entonces, como la figura que posibilita el recuerdo, la imagen que, para usar el término de Benjamin, permite "la porosidad" de las experiencias, del reencuentro del pasado con el presente.

La ciudad donde nací [y] me crié, la ciudad donde todo ocurrió.

Me escapé pero no se puede huir del paisaje de nuestros sueños. Mis pesadillas todavía ocurren en las calles de... (Vudú 56)

Esta cita del texto The Chill de Ross MacDonald, introduce la primera tarjeta postal que se titula "(Early Nothing)", una cita incompleta, que hace referencia a una ciudad que no se llega a nombrar, pero en la que se comparte la experiencia que toda ciudad que la infancia evoca. Con respecto a las citas que introducen las tarjetas postales, Cozarinsky dice que son "residuos de la lectura": "A esos objetos hallados, a la palabra escrita ajena quise confiar la continuidad de mi palabra escrita: la iluminación, brutal o pérfida, del texto que se acaba de leer y del que se abordará" (165). A través de la comunión entre el texto ajeno y el propio, se construye entonces la experiencia personal en la ciudad, cuyo caudal de imágenes proviene del Buenos Aires de los años treinta y cuarenta, y los territorios lejanos reencarnados por sus ancestros. Veamos una cita del texto "(Shangai Blues)":

Sí, los atardeceres de noviembre podían ser hipnóticos. A esa inapresable hora del día en que la luz vacila antes de desvanecerse y la noche se anuncia, aún antes de que pueda hablarse de brisa, con cierta humilde ligereza en el aire, cómo te gustaba observar los movimientos, recién descubiertos aunque anualmente repetidos, que anunciaban el verano. (94)

La trivialidad de las escenas que estos textos relatan, desde "[...] las amas de casa, cargadas de compras, impacientes en la cola del ómnibus, junto a los empleados de banco, con la camisa adherida tanto al cuerpo como al traje en un solo intento malestar" (94), hasta una conversación con su bisabuela "[...] único vínculo entre tus

Revista Iberoamericana, Vol. LXXXII, Núm. 257, Octubre-Diciembre 2016, 855-869 
padres casi gentilizados y una fe hebrea puramente gastronómica [...]" (94), generan contextos de recuerdos más que símbolos del pasado. A partir de la sensación corporal que producen la luz, los olores o la comida, "interesan no tanto por sí mismos sino por el recuerdo que evocan de otros lugares distantes, de otras situaciones remotas" (Sebreli 3). La luz, como una escena cinematográfica, acentúa un aspecto del relato que dirige la mirada hacia el lugar del encuentro. En este texto, la luz evoca una mirada nostálgica a través de la cual se presenta el foco de un turista que observa, con la distancia de un extranjero, pero que proyecta su deseo de captar el "espejismo" de una memoria auténtica.

Qué absorbente sentir, en el aire, a tu alrededor, esos cambios apenas tangibles, mientras la ciudad ponía en escena multitudes anodinas. Qué fácil quedarse. Observar. Sentir. Quedarse. (95)

La disputa por el lugar que ocupa el narrador en la construcción de las postales, dentro del relato del recuerdo o, fuera, como el turista con una mirada limitada sin el derecho a "quedarse" en el sitio que visita, es el hilo conector que arma El álbum de tarjetas postales del viaje. La misma idea de "álbum" personaliza la experiencia y constituye el aspecto autobiográfico del relato, recuperando un significado más íntimo de la experiencia del viaje del recuerdo. A su vez, el deseo de hospedarse, en el sentido derridiano de la palabra de ser bienvenido e incluido en el discurso local, parece ser también lo que el narrador intenta negociar. Esto es, el recuerdo ya no aloja al narrador, las imágenes del pasado solo permiten una estadía temporaria, una experiencia fantasmagórica que solo abarca el "afuera".

Es aquí donde podemos ver también la influencia de Borges en la poética de Cozarinsky. En las tarjetas postales podemos ver dos gestos borgianos que se recobran en el transcurso del texto: el relato sobre Buenos Aires, que nos remonta a poemas de Fervor de Buenos Aires, en los cuales se describe la ciudad a través de su luz, sus atardeceres y resplandores en los patios de los barrios bonaerenses. Así como la figura del escritor turista o "falsario" que Borges elabora en El escritor argentino y su tradición, donde llama turista a aquél que se excede en el uso del color local. Es precisamente, en ese espacio entre exceso y deseo del objeto argentino, donde se establece la experiencia del exilio en este texto. En el recobrar, desde la distancia, el derecho a narrar lo perdido.

"(Early Nothing)" brinda un buen ejemplo de lo antedicho, a través de la descripción de la experiencia cinematográfica en la que, hasta los niños son capaces de "advertir la textura de la pantalla", las fisuras de la imagen que se proyecta, sin que se contamine su "fascinación por las imágenes fugaces". Este texto relata también la imposibilidad de los ciudadanos de Buenos Aires de distinguir " [...] las ficciones políticas y sociales [que] fueron proyectadas, como tantas diapositivas, sobre la pantalla argentina:

Revista Iberoamericana, Vol. LXXXII, Núm. 257, Octubre-Diciembre 2016, 855-869 ISSN 0034-9631 (Impreso)

ISSN 2154-4794 (Electrónico) 
despotismo ilustrado, baño de sangre folclórico, democracia liberal, depredaciones militares y populistas" (57).

A través del paralelismo entre ambos "simulacros", el discurso cinematográfico y el político, el narrador busca un relato en el cual pueda incluirse, con el anhelo por un pasado de juventud y participación política: "De pronto teníamos conciencia de haber estado tomando una ficción por realidad y ni siquiera los que más encarnizadamente procuraban vivir a la altura de sus sueños deseaban un papel en una obra que no habían elegido". La referencia a un pasado de comunidad, al lugar que ocupaba el narrador en la escena que se está ritualizando, representa entonces el estado melancólico de su presente, en el cual se sustituye el original, con su réplica, creando un tipo de souvenir, un objeto que impide una identificación absoluta pero que construye su deseo por una experiencia auténtica de identidad.

Es quizás la postal "(Star Quality)", donde mejor se focalizan las ansiedades del escritor extranjero a través de la lente del turista. En este texto, el narrador se suma a la fascinación histórica con Eva Perón, objeto de deseo del imaginario argentino, cuya función primordial crea la división entre un "nosotros" y un "ellos", patriotas y traidores. "Esa mujer", como Rodolfo Walsh la ha nombrado, monumento que se ha encargado de definir los contornos de la nación, durante el pasado que el narrador recuerda, ha logrado seducir hasta a los intelectuales más antiperonistas. Cozarinsky se suma a ese llamado:

Anoche soñé con ella. La vi en la pantalla de televisión, toda de gris y azul, y no parecía sentirse a gusto. Quería volver a la radio y le prometí ayudarla. La ausencia de feedback nos dejó, a ella con un aire desconsolado y a mí con un resabio de impotencia. Esta mañana, al despertarme ya sabía que nunca iba a hacer un filme sobre ella. Había jugado con la idea durante años. Había puesto por escrito secuencias enteras. Había visto en mi mente imágenes precisas -recuerdo cómo estaban iluminadas, donde un corte las unía y las separaba-. Tal vez no lo intento por puro cobarde. ¿Qué temo? Que la ambigua fascinación que ella me inspira no sea la hagiografía reclamada por sus fans desamparados? ¿Que me insulten? ¿Que intenten atacarme? O acaso temo que si me arriesgo yo mismo me convierta en uno de ellos? (71)

El cuerpo de Eva entre los escombros de tantas escenas repetidas, de tantas imágenes proyectadas refleja un deseo de posesión erótico y, a su vez, clandestino. Esa experiencia privada del narrador con su objeto por un lado se escapa de la "sacralización del sitio turístico" (MacCannell 135) que es Eva, para hacerlo partícipe de la adoración popular, que convierte al narrador en "uno de ellos". Sin embargo, a pesar del exceso de ficciones que ese nombre evoca, la de la televisión, la del sueño, la de la radio, refleja también la lucha que existe en el imaginario nacional por construir la imagen auténtica, por adueñarse del objeto simbólico que define la nación y el lugar marginal que ocupa el escritor exiliado en el momento de nombrar lo que cree propio.

Revista Iberoamericana, Vol. LXXXII, Núm. 257, Octubre-Diciembre 2016, 855-869 
Las tarjetas postales de Cozarinsky reflejan la ansiedad de un exiliado que se cuestiona cuán legítimo es su discurso, cuán auténtica su mirada. Recordemos que Cozarinsky se exilia en Francia, "sin valerse del título de exiliado" y se marchó porque ya no podía vivir en una sociedad "tan opresora y donde no se podía respirar" (Cisterna Gold, Exilio). El lugar de extranjero en su propio hogar que Cozarinsky se construye para sí mismo, un lugar que intenta deshacerse de zonas políticamente recargadas, le permite escribir sobre escenas porteñas de su juventud, tanto íntimas como públicas. Mediante una discusión en torno al lugar que ocupan esos discursos en el imaginario argentino, se elabora un debate nuevo en torno al acceso y el lugar que se le asigna a aquel que escribe desde "afuera". Para Cozarinsky, el momento del déjà vu en el cual se reclama la experiencia del pasado desde un presente dislocado, capta mecanismos de escritura que convierten el mito del original, y en este caso el mito es metonímicamente Eva Perón, en un espacio de disputa que reemplaza la idea de hogar con su fantasía.

El texto de Chefjec desde su primera página impone un lugar incómodo de enunciación, cuestiona la localidad de su discurso como problemática que se va a desarrollar a lo largo del texto. Si bien estructuralmente este texto empieza también como el de Cozarinsky, en el comienzo del viaje y en el momento de la despedida como lugar inaugural de mucha de la literatura de exilio, en Los incompletos, hay muy poco que recordar. El relato es un tratado sobre la memoria: invoca el recuerdo o el "no olvido", como sugiere el narrador, de "algo que ocurrió una noche. Hace varios años atrás, y los hechos relacionados de la mañana y la tarde siguientes" (7). Al invocar el "no olvido" en vez del "recuerdo", solo hará mención de los elementos que se recuperan del pasado, como lo fragmentario e incompleto de la historia personal. Desde este punto de vista, será poco lo que podremos recuperar de lo que constituye a estos personajes, más que las diferentes impresiones que se abordan en las cartas. Se trata de un texto que se convierte en una mirada interesante con respecto al trabajo de la memoria, de la manera en que el pasado se recupera a partir de las posibilidades éticas y políticas de la reunión y la intimidad. La memoria y el recuerdo se convierten en un tipo de relación e intercambio personal, un contacto que sólo se hace evidente a través del "silencio" que la lectura y la distancia transmiten. Según Jacques Derrida "[f]riendship does not keep silence, it is preserved by silence. From its first word to itself, friendship inverts itself. [...] Friendship tells the truth - and this is always better left unknown.[...] Speech ruins friendship; it corrupts by speaking, degrades, belittles, undoes the speech of friendship"(53-4). Desde este punto de vista, sugiero que el relato de Chefjec encuentra el valor inmediato de la amistad en lo que no se dice, en el afuera del discurso e intenta crear otras posibilidades para la comunicación.

De esta manera, Félix, "un planeta errante, impregn[ado] de las lenguas que iría adquiriendo y [...] adopta[ndo] un impreciso lustre internacional (pero conservando, como una témora ambigua, extenuante y codiciable a la vez, apenas visible aunque indeleble, la sustancia de ser un argentino en fuga)" (7; énfasis mío), relata su solitaria

Revista Iberoamericana, Vol. LXXXII, Núm. 257, Octubre-Diciembre 2016, 855-869 ISSN 0034-9631 (Impreso) 
estadía desde un hotel en Moscú. La realidad de un "argentino en fuga" se refleja a través de su experiencia y descripción de esa distancia, una soledad que se vive en los detalles, en los limitados movimientos que se encuadran dentro del espacio de la habitación así como de las observaciones, los mínimos recuerdos y escenas. Esto es, no estamos frente a un escritor turista, sino más bien ante un viajero ya desnudo de las subjetividades modernas del viajante que vive en la constante imposibilidad del aposento. Al igual que en las tarjetas postales de Cozarinsky, el espacio y la experiencia se vuelven el objeto que se va construyendo a lo largo del relato. La novela es en efecto el resumen de las cartas escritas por Félix al amigo que lo despidió y quien a su vez decide comentar sobre la misma experiencia de esa despedida. Este lector de cartas, se ve en la encrucijada de interpretar, orientar los viajes de Félix, anticipar sus aventuras y preocuparse por los posibles desvíos. La escritura de las cartas refleja la necesidad de un lector que pueda descifrar el secreto, el código que solo años de amistad pueden revelar. Se trata de un lector privilegiado, cuya autoridad no se basa en un saber cultural o epistemológico, sino más bien uno proveniente de una historia personal e íntima, un testigo con información alternativa que debido a la posibilidad de su relato, revela la relación afectiva entre los personajes así como el contacto emocional que se va construyendo con el lugar donde el personaje reside. Mientras que la amistad que se describe en el texto de Cozarinsky se inscribe en el compromiso político de los 60's y una historia política donde la lealtad y la afiliación ideológica constituyen alianzas amenazantes, la relación entre Félix y su amigo despliega una ambigüedad de fundamento, un pasado incierto y nebuloso que permite pensar la amistad desde un lugar incierto pero mediado por la sensibilidad y los sentimientos.

A partir de esa dinámica se generan espacios de residencia en un Moscú inhóspito blanqueado por la nieve, el invierno y el hotel donde se hospeda Félix, y vive una cotidianidad a veces trivial y otras desgarrante. Dichas descripciones no llegan a encapsular una imagen que abarque el referente del pasado visible más que en la sensación de su recuerdo:

Ignoraba el mecanismo mental que siempre lo llevaba a comparar dimensiones y reparar en contrastes; era como una tendencia aberrante de la observación, alerta en primer término a la supuesta desarmonía y a la discontinuidad. Pero más de una vez esa desarmonía se le había evidenciado falsa, o a la inversa, del todo verdadera o natural, y por lo tanto obvia e irrelevante. Entonces sentía que su misma percepción era el elemento sin ajuste, que a lo mejor una tara antigua o una condición cultural, o las dos cosas a la vez, lo llevaban a tener ese tipo de pensamiento y, digamos de sensibilidad. (59-60)

El recuerdo se manifiesta como un tipo de "sensibilidad" subjetiva y no como un referente estable y reconocible ni como un pasado capaz de diferenciarse, como

Revista Iberoamericana, Vol. LXXXII, Núm. 257, Octubre-Diciembre 2016, 855-869 ISSN 0034-9631 (Impreso)

ISSN 2154-4794 (Electrónico) 
"verdadero o natural". Un reconocimiento que pasa por los sentidos más que por su valor discursivo. Y es a través del reconocimiento de esa "sustancia", que el narrador describe a la Argentina, como

un país sinónimo de espacios abiertos, sinónimo de amplitud, desafuero y vacío, como lo es Australia; y Félix suponía que quizá el contraste entre ésta imagen del país, recibida de la infancia, y su experiencia de lo excesivamente concentrado (la aglomeración familiar, la falta de espacio en la escuela, el hacinamiento barrial, etc.) habían producido esa sensibilidad desviada, una especie de testigo siempre alerta a las proporciones y medidas desajustadas. (60; énfasis mío)

Y como la justificación de esa "sensibilidad desviada" como esencia de su "origen", estos "espacios representacionales" en los términos de Lefebvre, son espacios que se "viven", a través de los cuales se crean "imágenes y símbolos" responsables de construir un referente cultural, una idea de lugar propio. Espacios con un "affective kernel or center: Ego, bed, bedroom, dwelling, [...] church, graveyard. It embraces the loci of passion, of action and of lived situations" (42). Para volver entonces, a la idea con que se inicia este trabajo, el hotel es el lugar figurativo que recoge "lo inasible" de la identidad dentro del mapa afectivo. No solo toda la novela de Chefjec transcurre en un hospedaje, sino que se vuelve la imagen que la tarjeta postal construye. Si la idea del hotel por un lado, nos remite una vez más a la experiencia del viaje, al cuerpo en movimiento, desplazamiento y desconexión con el lugar de origen, este texto también hace uso de la misma imagen como espacio de encierro, lugar de paso que sitúa al sujeto en un lugar que marca el afuera. "En los hoteles se sentía una persona sin pasado, o más exactamente con pasado impreciso y disponible" (45). No obstante, como un "argentino en fuga" y con un pasado incierto, logra encontrar en ese pequeño recinto, un lugar que refleje la sensación de la deriva:

\begin{abstract}
Al fin recibe la llave y se ponen en marcha. Es la etapa ceremoniosa del hospedaje, ser admitido y guiado a los aposentos. El mostrador, hasta entonces, el relativo segundo plano, adquiere para Félix la importancia de un límite. Sabe que estar dentro del hotel es haber franqueado la línea de recepción, que estar fuera es no haberlo hecho. Todo lo existente más allá, cuando se lo mira, desde el otro lado, pertenece al pasado; y del mismo modo, si uno va y sale (o entra, dependiendo de la situación) todo lo que hay detrás, o sea aquello dejado hace un momento, también ha quedado en el pasado. [...] En cierto modo se siente atraído por las situaciones-prólogo, como las llama, estadios donde las cosas no avanzan: los momentos de transición, las antesalas, los intervalos o las pérdidas de tiempo en general, etc. (30)
\end{abstract}

Un lugar de frontera, que marca el límite entre el presente y el pasado, dependiendo desde el lugar que se lo mire. A partir de esa subjetividad, Félix crea un "mapa afectivo"

Revista Iberoamericana, Vol. LXXXII, Núm. 257, Octubre-Diciembre 2016, 855-869 ISSN 0034-9631 (Impreso) 
en los términos de Jonathan Flatley, no como una "representación estable de paisajes incambiables", sino como manera de presentar una "sensación" en las palabras de Félix, o "feelings" como dice Flatley, de "orientación" o dirección hacia un espacio reconocible en constante movimiento. Este itinerario afectivo se ve en la medida en que Félix intenta recordar algunas escenas de Buenos Aires, a través de las cuales reflexiona en torno al mismo ejercicio del recuerdo.

Pero pocas cosas le resultaban más equívocas que los pensamientos derivados de su ciudad; en algún momento se había producido un corte y ninguna de las situaciones, lugares o simplemente impresiones que recordaba pertenecía por derecho propio al paisaje de la realidad, [...] la actualidad se traducía una y otra vez, se actualizaba borrando su propia sombra, su sentido de la historia o la huella dejada en los seres humanos. (61; énfasis mío)

Es el espacio del presente, y la escritura de esa experiencia, lo que se "actualiza" y genera nuevos recuerdos, memorias que vuelven imposible una imagen que contenga "la realidad". Mientras que el personaje de Cozarinky busca maneras de relacionarse con los relatos del pasado, ya sea el propio, el relato de la tradición de la literatura de exilio (desde su lugar emocional de la política y la cultura a través de una mirada de turista), Chefjec se detiene en la experiencia de la distancia desde el espacio de los afectos, o sea desde el "in-between-ness" de dichos discursos. Según Seigworth y Gregg:

Affect is born in in-between-ness and resides as accumulative besides-ness. Affect can be understood then as a gradient bodily capacity-a supple incrementalism of ever-modulating force-relations-that rises and falls not only along various rhythms and modalities of encounter but also through the troughs and sieves of sensation and sensibility, an incrementalism that coincided with belonging to compartments of matter of virtually any and every sort. (2)

Los afectos viajan en los intersticios de la comunicación, y a través de los “sentidos", en un espacio casi ilegible que solo el cuerpo puede atestiguar. "Así la idea de un país propio y de una ciudad natal remitía para Félix al orden de lo documental o lo facultativo, una especie de acto de fe; era posible verificar el recorrido, se podía pertenecer a un lugar, pero eso no se traducía a la esfera de la realidad [...]" (Chefjec 62). El rastro del lugar de origen queda marcado en el cuerpo para ambos autores porque es el espacio donde se marca la memoria: para Chefjec el pasado se siente como "una huella dejada en los seres humanos" que el presente viene a "borrar" para dar lugar al futuro. Para Cozarinsky, es el déjà vu y la sensación de haber estado allí en tanto narrativa que se constituye a partir de otros textos y otros relatos.

Los dos textos comienzan con una despedida que incita el relato y el recuerdo. Como todo relato de viaje, la escritura se inicia en el después de la experiencia que

Revista Iberoamericana, Vol. LXXXII, Núm. 257, Octubre-Diciembre 2016, 855-869 ISSN 0034-9631 (Impreso)

ISSN 2154-4794 (Electrónico) 
hace que la memoria participe en la construcción del pasado y que haga de éste una ficción, una construcción volátil e insuficiente. No obstante, el texto de Cozarinsky busca un lugar en el relato de la historia, la posibilidad de reunión con una historia que lo acepte en la red afectiva que significa la escritura del exilio. Existe en Vudú urbano un sentimiento de culpa que intenta justificar la partida: el exilio, la dictadura, Perón y recobrar la sensación corporal y física del recuerdo como castigo y como otra manera de intervenir en el relato del cual no se siente partícipe.

Ya a comienzos del siglo XXI, el texto de Chefjec presenta otra manera de pensar la conexión con el otro y la subjetividad: construye personalidades efímeras, sensaciones que no remiten ni necesitan de un lugar legible que los ratifique. Se vuelven personalidades que buscan en la carta "lo incompleto" de su ser a pesar de que por definición las cartas busquen un reconocimiento. Se trata de un texto que se dedica a poner en evidencia la imposibilidad de una "realidad" que construya el pasado, y así el relato que se genera es uno a partir del "no olvido", un recuerdo "literalmente" nebuloso, imposible. Chefjec replantea formas de pensar la fraternidad desde el lugar de la distancia. A pesar de la soledad en la que vive el personaje, la extranjeridad en un país remoto, el texto construye una experiencia emocional, una intimidad que se genera en el pacto entre Félix y el narrador, así como entre Félix y los otros personajes que viven en el hotel. Como la figura latente de los planetas en mucha de la literatura de Chefjec, que conviven cada uno desde la construcción de sus respectivas órbitas, cada uno desde su eje referencial y esencial, quedan no obstante sometidos a la construcción de su propia realidad pero inevitablemente ligados, en comunión a la esfera donde circunda el otro. Las cartas y las tarjetas postales entonces son el pacto que reclama dicho contrato afectivo, la firma que sella la relación entre sujeto y objeto, "entre" ("among") para decirlo con Derrida, autor y lector. "Una aclaración [dice el amigo de Félix] [...] innecesaria y para [...] otr[o] ilegible. Su firma parecía un ideograma privado que nunca me preocupé por entender o descifrar. Sabía que era suyo y eso bastaba" (Chefjec 190). Un pacto elusivo que despliega no obstante un contacto íntimo y "en silencio", y una manera alternativa a la distancia de pensar la intimidad.

\section{BiBLIOGRAFÍA}

Amante, Adriana. Poéticas y políticas del destierro. Argentinos en Brasil en la época de Rosas. Buenos Aires: Fondo de Cultura Económica, 2010.

Chefjec, Sergio. Los incompletos. Buenos Aires: Alfaguara, 2004.

Cisterna Gold, María Inés. Exilio en el espacio literario de la posdictadura. Reino Unido: Tamesis, 2013.

"La vida en suspenso. La figura del hotel en Hotel Edén de Luis Gusmán". Ciberletras 26 (dic. 2011) <http://www.lehman.cuny.edu/ciberletras/v26/ cisternagold.htm>. 19 ago. 2016.

Revista Iberoamericana, Vol. LXXXII, Núm. 257, Octubre-Diciembre 2016, 855-869 
Cozarinsky, Edgardo. Vudú urbano. 1985. Buenos Aires: Fondo de Cultura Económica, 2000.

Derrida, Jacques. The Politics of Friendship. George Collins, ed. London: Verso, 1997. Márgenes de la filosofía. Madrid: Cátedra, 1998.

Flatley, Jonathan. Affective Mapping. Melancholia and the Politics of Modernism. Cambridge: Harvard UP, 2008.

Lefebvre, Henri. The Production of Space. Donald Nicholson-Smith, trad. Malden: Blackwell Publishing, 1984.

MacCannell, Dean. The Tourist. A New Theory of the Leisure Class. Berkeley: U of California P, 1999.

Mathias, Bettina. The Hotel as Setting in Early 20th Century German and Austrian Literature. Checking in to Tell a Story. UK: Camden House, 2006.

Piglia, Ricardo. Formas breves. Buenos Aires: Temas Grupo Editorial SRL, 1999.

Seigworth, Gregory y Melissa Gregg, eds. The Affect Theory Reader. Durham: Duke UP, 2010.

Stewart, Susan. On Longing. Narratives of the Miniature, the Gigantic, the Souvenir, the Collection. Durham: Duke UP, 1993.

Van den Abbeele, Georges. Travel as Metaphor. From Montaigne to Rousseau. Mineapolis: U of Minessota P, 1992.

"Sightseers: The Tourist as Theorist." Diacritics 10 (dec. 1980): 2-14. 
